
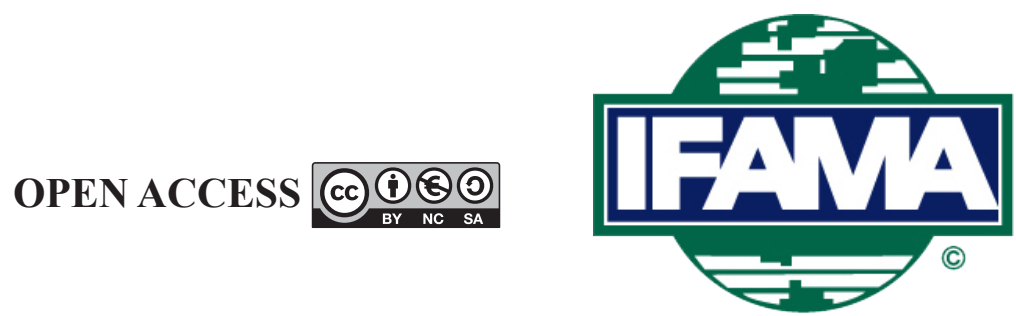

International Food and Agribusiness Management Review

Volume 25, Issue 1, 2022; DOI: 10.22434/IFAMR2020.0142

Received: 2 September 2020 / Accepted: 26 April 2021

\title{
Do farmer groups improve the situation of women in agriculture in rural Kenya?
}

\section{RESEARCH ARTICLE}

\author{
Rose Ingutia $^{\text {(aa }}$ and John Sumelius ${ }^{\mathrm{b}}$ \\ ${ }^{a}$ Postdoctoral Researcher, ${ }^{b}$ Professor, Department of Economics and Management, Faculty of Agriculture \\ and Forestry, University of Helsinki, P.O. Box 27, Latokartanonkaari 5, 00014, Helsinki, Finland
}

\begin{abstract}
Production by smallholders in rural Kenya is limited by institutional, technical and investment constraints. Female farmers are the majority among smallholders and have significant roles in agriculture; nonetheless, they face constraints in accessing resources. Recent primary data of 347 farmers (proportional random sampling) was used to examine: (a) factors affecting women's participation in agriculture; (b) factors influencing female farmers' decision to join a farmer group; and (c) the effect of women's membership in a farmer group on crop yield. We applied Probit and linear regression with endogenous treatment maximum likelihood methods. Results reveal that women's participation is positively influenced by membership in a farmer group and land ownership. Women's decision to join a farmer group is positively affected by access to credit, and negatively by limited decision-making power and lack of access to land. Crop yield is positively affected by membership years in a farmer group and ownership of mobile phones, negatively by lack of credit. Farmer groups are a particularly effective platform to improve crop yields and other constraints confronting female farmers. Surprisingly, this platform is under-utilised. Policymakers should invest in human, financial and physical capital of farmer groups as a pathway to rural development, improved rural livelihoods and reduced poverty.
\end{abstract}

Keywords: farmer groups, female farmers, crop yield, rural Kenya, productive resources JEL code: Q18, Q71

\footnotetext{
(i)Corresponding author: rose.ingutia@helsinki.fi
} 


\section{Introduction}

A majority of the rural population in sub-Saharan Africa (SSA), including Kenya, has agriculture as their main occupation (Davis et al., 2017; FAO, 2011). A large percentage of the farmers are smallholders who live in regions of degraded lands of poor soil quality dependent on uncertain rainfall, thereby exacerbating their vulnerability to climate variability and lacking secure tenure (Grist, 2014; World Bank, 2008). A modest percentage of the rural people are wage labourers, displaced people and pastoralists. Across all categories, women tend to be the majority, because men migrate to the cities in search of work, thus several households are headed by women (Hill, 2011; World Bank, 2007), therefore women must engage in farming. The contribution of women to labour in African agriculture is in the range of 60-80\% (FAO, 2011). Recent evidence using individual plot-level labour input data from nationally representative household surveys across SSA countries showed that the average female labour share in crop production varies from over $50 \%$ in countries like Malawi to below $24 \%$ in countries like Niger (Palacios-Lopez et al., 2017).

Bobonis (2009) and Palacios-Lopez et al. (2017) report that women in Africa produce a large percentage of the continent's food, including both subsistence and market food on small landholdings; they also process the food, provide storage for and market the food. These reports suggest that women play an indispensable role in contributing to economic welfare and food security. Moreover, women's increased income is associated with greater food consumption and improved nutritional status of their households. Despite the significant roles rural women play in agriculture and food security, the extent to which women and men can access and benefit from productive resources differs (IFAD, 2016). Women often face greater challenges in access to and control over productive resources (Asiedu, 2012; IFAD, 2011; Meinzen-Dick et al., 2014; Mikalitsa, 2010; Naadira, 2012).

For instance, there is a wide disparity in the proportion of women holding agricultural land, ranging from 5\% in Mali to 30\% in Botswana and Malawi (FAO, 2011). Consequently, there is a disproportionate representation of women among the landless who face food insecurity and are unable to meet basic needs. This tends to push women into wage farm labour, which not only endangers their livelihoods (FAO/IFAD/UNICEF/ WFP/WHO, 2019) but also exacerbates their onerous daily tasks (Chinyoporo, 2017) and household-level inequalities, such as being voiceless in determining household priorities, spending patterns and distribution of benefits (Quisumbing and Maluccio, 2000).

The multiple constraints in the inequitable distribution of productive resources limit women's effective participation in agriculture and compromise women's production potential, thereby contributing to low crop yields with detrimental effects on the economic welfare of rural populations, food security and the price of food. This turn of events contributes to the high percentages of Africa's populations suffering from malnutrition; Africa is the only continent known to be experiencing rising child malnutrition, causing twothirds of child deaths (Akombi et al., 2017; UNICEF, 2013).

Increased research and development efforts have addressed productivity and market failures that smallholders face in developing countries, nevertheless, the status quo of the farmers has not led to positive outcomes. What can facilitate women's access to productive resources such as land, agricultural inputs, technology, financial services, market information, and extension services (Markelova et al., 2009; Mojo et al., 2007) resulting in increased women's participation in agriculture, increased food security, improved maternal and child nutrition as well as better rural livelihoods? Farmer groups can play important roles in overcoming the constraints faced by rural women; evidence shows that efficient farmer groups can empower their members economically and socially by offering them a range of services that facilitate access to productive resources (FAO, 2012; Sumelius et al., 2015; Wanyama, 2014). We identify a research gap on finding out the enabling conditions for female farmers to gain better access to productive resources and for making female farmers participation in agriculture more effective. 
Several studies indicate that farmer groups improve crop yields, leading to outcomes such as: (a) increases in food security through greater access to land, financial services, agro-inputs like fertiliser, pesticides, herbicides, agricultural machinery, and farm implements through subsidiaries at reasonable prices (Nkuranga and Wilcox, 2013; Saito et al., 1994; Spielman et al., 2011); (b) increases in women's income via the marketing of products through cooperative networks and diversification into profitable areas (Lecouetre, 2017); (c) offering micro insurance at affordable prices to meet the needs of the uninsured women (Banthia et al., 2009); (d) diversification of rural livelihoods through improved functional literacy, training programmes to improve farmers' skills and innovation and providing technical leadership and business development services (Floro, 2002); (e) providing clean, abundant accessible water for irrigation, sanitation, and hygiene to improve health and nutrition, and to reduce the workload of women (Fletschner, 2009; Fletschner and Kenney, 2011); and (f) cultivating nutrition programmes to improve the quantity, quality, price, use and governance of nutritious foods and to increase women's resiliency to economic and climate-induced food insecurity (Miller, 2001; Smith et al., 2003).

The findings of the majority of the studies suggest that farmer groups' activities have transformed agricultural productivity, consequently improving the wellbeing of farmers in general. Nevertheless, some studies, including Poulton et al. (2010) and Mwaura (2014), report that farmer groups fail to impact farmers positively. These contradictory findings could be partly due to the diverse nature of farmer groups as well as the analytical methods used. To underscore the minimal impact of farmer groups on farmers, the Food and Agricultural Organization (FAO, 2018a) indicates that the number of people in the world affected by undernourishment or chronic food deprivation is particularly high in South Asia and most regions of Africa; furthermore, women are more likely than men to be affected by severe food insecurity. Also, Beegle et al. (2016) project that the world's extreme poor will be increasingly concentrated in Africa. These alarming reports call for further assessment of the contribution of farmer groups in addressing the performance of smallholders, particularly women.

A greater part of the rural population's livelihood is rainfed agriculture on small, degraded lands of poor soil quality, and women happen to be the majority in Kenya. Women's agricultural activities range from agricultural production to the marketing of the products, thereby contributing to food security and better income levels. However, women face constraints in accessing productive resources due to social-cultural factors. Consequently, women lack secure land tenure surmounting to lack of collateral to get credit from banks. Farmer groups are a potential platform that can facilitate women farmers' access to input and output markets. Small-scale institutional innovations initiated by farmer groups tend to minimise inefficiencies in input and output markets (Barrett et al., 2012). Unfortunately, little research has been done on how farmer groups can help women farmers. In Kenya, farmer groups' linkage of smallholders to small and mediumsized agro-enterprises aim to reduce transaction costs in both input and output markets by supporting and improving smallholders' competitive advantage and bargaining power has resulted in poverty reduction and rural development (Schneider et al., 2010). Olagunju et al. (2021) found technical efficiency of members of cooperatives was constantly greater than that of non-members.

\subsection{Study's objective and research questions}

The overall aim is to investigate the circumstances that hinder women farmers from being successful in agribusiness management. The specific research questions are the following:

- Which factors affect women's participation in agriculture?

- Which factors influence rural women's decision to join a farmer group?

- Does women's membership in farmer groups affect crop yield?

The term crop yield means output per unit of land and is the measure of crop produced per area of land. Crop yield is easy to measure and is an important metric because it helps in understanding food security (Fischer et al., 2014). Female farmers mostly have low yields due to little inputs, lack of knowledge and irrigation possibilities and yet not much is known about the impact of farmer groups on female farmers because a 
majority of the current empirical studies are on farmer groups and farmers in general, with little research on female farmers specifically. We hypothesise that membership in a farmer group improves female farmers' crop yield.

Gender bias and lack of disaggregated data have inhibited the focus on those most in need of achieving sustainable development. The present study echoes and contributes to ongoing studies strategising specifically female farmers with specific problems in specific places - rural areas (Kharas et al., 2019). We attempt to identify and understand female farmers (their characteristics), the kinds of constraints they face and the root causes of the constraints and potential ways out (cooperatives). In the rural areas, we targeted, to our knowledge we are the first to carry out a face-to-face survey focusing on female farmers. The personal interview survey we carried enabled exploring the responses of female farmers, thereby gathering more and deeper information.

This study is important due to women's significant contributions to crop yields. Investigations in female farmers will lead to increased crop yields, food security, and nourishment, thereby enhancing human productive capacity and better livelihoods for rural populations. Farmer groups are a potential platform to combat social-cultural norms that are oppressive to women. The findings can be applied to facilitate better service delivery by farmer groups, thereby enhancing female farmers' participation in agriculture. Furthermore, the empirical insight on the impact of farmer groups on farmers' yield has policy implications, especially for governments, donor agencies and agribusiness companies in changing policies or repackaging services for gender equality to promote smallholder productivity.

\section{Literature review of smallholder farmers and farmer groups in Kenya}

The multiple constraints female farmers face including lack of credit, missing marketing opportunities, lack of cooperatives and companies for providing input, credit as well as low yields and possibly lack of extension and irrigation and marketing opportunities prompt women to become members of farmer groups. In this study, a farmer group is defined as 25-35 farmers who support each other to serve their common interests; farmer groups are normally informal. A majority of the members are smallholders doing subsistence farming, whereas agricultural cooperatives are mostly formal groups with a larger membership, usually large-scale commercialised farming (Weenik et al., 2007). Farmer groups can transform into cooperatives with time if they expand enough to meet the requirements of becoming a cooperative. Our focus is on farmer groups because a majority of farmer organisations in rural Kenya consist of farmer groups.

Smallholders play a significant role in Kenya's agricultural production; they predominate in both cash and food crop production. However, smallholders' yield per hectare is lower in comparison to large-scale farmers due to: (1) dependence on rain-fed agriculture; (2) the impact of environmental degradation; (3) lack of application of modern farming technology; and (4) dwindling access to farmer support services due to the government's liberalisation of the agricultural sector (FAO, 2005; Larson et al., 2014; Riesgo et al., 2016).

The proportion of Kenyans living on less than the international poverty line (US\$ 1.90 per day in 2011 PPP) declined from $46.8 \%$ in $2005 / 06$ to $36.1 \%$ in $2015 / 16$. The latest available data for Kenya's rural poverty is $49.1 \%$ in 2005 , based on the percentage of the rural population living below the national rural poverty line (World Bank, 2018). Kenya is among the low-income food-deficit countries (LIFDC), as well as one of the 51 African countries requiring external assistance for food. Kenya's food deficit is largely due to consecutive unfavourable rainy seasons culminating in severe drought conditions that affect crop and livestock production. About 2.35 million people are severely food insecure, mainly located in eastern, southeastern and coastal areas (FAO, 2018b). 


\subsection{The situation of women in agriculture}

A large percentage of rural women are illiterate. Illiteracy is characterised by poverty and hunger, ignorance about nutritional requirements and is mainly a rural phenomenon that hinders rural development and food security. Illiteracy also threatens productivity and health, and limits opportunities to improve livelihoods, particularly for rural girls and women (FAO, 2005). Educated mothers are more knowledgeable about the benefits of small family size and thus will opt for family planning, in the process reducing fertility rates, thereby improving the quality of children born to them and the quality of life for both the children and themselves (Ingutia, 2017).

Women's access and control over land are crucial in empowering them economically, socially and politically. However, women's attempts to access and gain control over land are constrained due to social inequalities associated with customary and traditional tenure systems and reinforced by a lack of enforcement and implementation of new land laws and policies on gender equality in gaining access and control over land. On the other hand, rural women are allocated a small piece of land (not ownership) by their husbands to produce food crops including vegetables meant for home consumption and to a lesser extent for sale. The family plot used for cash crops takes priority, however, leaving women with limited time to work on their plots (Naadira, 2012; World Bank, 2008).

Female farmers lack collateral (usually land), and have a limited scale of enterprises, and thus are disadvantaged in accessing credit and loans. The terms of access to rural loans usually favour commercial enterprises, excluding important aspects related to food production and household nutrition. Moreover, women have less time and money to travel to credit institutions, which typically are situated in urban centres (Fletschner, 2009; Fletschner and Kenney, 2011). Female farmers receive only $1 \%$ of the total credit to agriculture, which negatively affects their incentives in pursuing productive income-generating opportunities (FAO, 1995).

Access to improved seeds, fertilisers and pesticides is limited mostly because extension services fail to cover women, and government subsidised inputs are generally not granted to women. Furthermore, women tend not to have the cash needed to purchase the subsidised inputs. Lack of appropriate technology has caused the production among women to be predominantly labour intensive, with most of the farm work done by family and child labour. High illiteracy levels among rural women is a barrier to accessing the benefits of research and innovation. Female farmers' main domain is food crops that are of low priority in research, while at the same time, their roles and needs are often ignored in the creation and implementation of new technologies (Mikalitsa, 2010).

Women also face constraints such as a lack of mobility, a shortage of qualified female extension staff, inappropriate extension packages and a lack of flexibility in extension services, with timetables that are not always compatible with women's daily chores. Projection in many extension services is oriented towards crops traditionally grown by men, and in some cases, cultural factors prohibit women from receiving training (Adenkule, 2013; Meinzen-Dick et al., 2014). Low-income women tend to be marginalised by distant and poor market facilities. Insufficient emphasis has been placed on market facilities that attract the participation of women in marketing. Market information remains confined to the literate as well as more urban-based farmers at the expense of rural women. Information, particularly on food security, fails to reach female farmers (Asiedu, 2012; IFAD, 2011).

Table 1 depicts selected characteristics of women in Kenya; the low percentages of women in ministerial level positions and female land ownership, among others, suggests that social-cultural norms tend to limit women's participation in decision-making. Indeed, their presence in decision-making bodies, especially in leadership, remains weak, subsequently, their needs particularly as farmers rank low in policy and resource allocation. Consequently, female farmers produce below their production capacity (FAO, 2012). At the household level, women have no bargaining power or voice to influence decisions in production and marketing, including plot selection, the crop and variety to be planted, land preparation, fertiliser application, pesticide application, 
Table 1. Selected characteristics of women (\%) in Kenya 2000-2018 (World Bank, 2019).

\begin{tabular}{lll}
\hline & Female & Male \\
\hline Family planning needs met & 68 & \\
\% of firms with female participation in ownership & 48 & \\
\% of firms with female top managers & 16 & \\
Proportion of women in ministerial level positions (\%) & 23 & \\
Women deciding on contraceptive use (\%) & 56 & 50 \\
Employment in agriculture (\% of female / male employment) & 64 & 57 \\
Bank account ownership female/male (\%) & 46 & 30 \\
\% of women/men who own land alone (not joint ownership) & 7 & 70 \\
Mobile money account ownership female/male (\%) & 62 & 50 \\
Self-employed (\% of female/ male employment) & 79 & \\
\hline
\end{tabular}

labour hiring, harvesting, sale of farm produce, purchase and sale of farm machinery, purchase and sale of land, use of the proceeds from the farm and saving.

The impact of gender inequality in accessing productive resources can be summed up from the key message of the State of Food and Agriculture (FAO, 2011). The report states that gender equality would subsequently increase yields on women's farms by $20-30 \%$, and consequently, agricultural output in developing countries would increase by $2.5-4 \%$, thereby reducing the number of hungry people in the world by $12-17 \%$. Socialcultural institutions still override the constitution of gender equality, the former prohibit or restrict women from owning land. Therefore, support to women farmers can contribute to women's access to productive resources if farmer groups and cooperatives are provided gender equality training and are in support of these measures, and simultaneously set gender equality strategies or gender equality plans of action (Duguid and Weber, 2016; Sexsmith, 2019).

\subsection{Farmer groups}

The situation of female farmers reflects the circumstances of smallholders in general since female farmers are the majority. Smallholders in Kenya are predominantly resource poor, and their participation in commercialised production is generally limited by various institutional, technical and investment constraints. Faced with these constraints, particularly access to productive resources in the pursuit of guaranteeing household food security and maximising income from agriculture (Bibby and Shaw, 2005; Birchall and Simmons, 2009), individual farmers from the grassroots-level pool their resources and work together as members of farmer groups. Farmer groups have existed since the precolonial era, the earlier farmer groups were informal and seasonal self-help groups. Presently, farmer groups range from small informal groups to large formal cooperatives (Poole and Frece, 2010).

The informal groups are largely self-help groups and are built around customary principles and ideas of promoting and protecting individuals as well as collective wellbeing. Farmer groups are groups of farmers that leverage collective action to access certain services, including the exchange of information, providing representation and voice to members, the marketing of produce and the buying of inputs. The economic benefits from the sale of farm products are normally distributed to members after covering transaction costs (Shiferaw and Muricho, 2011). Governments, development agencies and agribusiness companies have embraced farmer groups' approaches because the majority of smallholder farmers are members of farmer groups; these groups are suitable pathways to reach the very poor at the grassroots level. Moreover, the delivery of extension services, including credit, input, marketing, technical training and education, is done through the channel of the group approach. Farmer groups allow for farmers to interact with each other while sharing knowledge, experiences and resources (Ainembabazi et al., 2017; Bernard et al., 2008a; Wanyama et al., 2009; Woomer et al., 2004). 
Extension services mainly involve technology transfer, with the village extension worker transferring knowledge from the research station to farmers by using farmer groups or mass media methods. The elite of the rural communities typically captures the services and resources, while the poor and women are excluded or receive very little benefits. Minimal efforts have been made to train group leaders, group members or the village extension workers (Chamala and Shingi, 1996).

The same socio-economic constraints that limit women's access to productive resources, often challenge their participation in farmer groups. A case in point, female membership in agricultural cooperatives is limited because women fail to meet membership requirements such as land ownership. However, there are some cooperatives and farmer groups formed with both flexible membership requirements and to suit activities traditionally performed by women, including horticulture, small animal husbandry and food crop marketing. These cooperatives and farmer groups work with female farmers: (a) through the power of association; farmer groups normally demonstrate their capacity to help smallholders to overcome barriers and gain better access to resources, thereby enabling them to increase their crop yields; and (b) by offering networks of mutual support and solidarity that allows women's social capital to grow, improving their self-esteem and self-reliance. This enables women to acquire a stronger voice in decision-making and to collectively negotiate better contract terms, prices and access to a wide range of resources and services including agricultural resources and assets, markets to commercialise their produce, and credit, capital and other financial and social services.

Differences in dynamic and lagging regions present smallholders with different opportunities and challenges; consequently, farmer groups in Kenya operate at various levels, depending on their respective circumstances. Some smallholders are successful in marketing high-value perishable products such as fruits, vegetables and milk, but a majority are not. Some are still net sellers of food, whereas others are net buyers. Some resort to non-farm income in situations where many opportunities abound; conversely, there are situations where nonfarm income is a coping strategy that prevents or slows their descent into deeper poverty. A study by Sumelius et al. (2015) on cooperatives' competence in reducing poverty in Tanzania concluded that cooperatives' business models for poverty reduction can take very different forms. While some cooperatives were not effective in poverty reduction, others had succeeded in improving the living conditions of their members.

Figure 1 is on the conceptual framework of women farmers productivity with farmer groups as a platform to boost productivity.

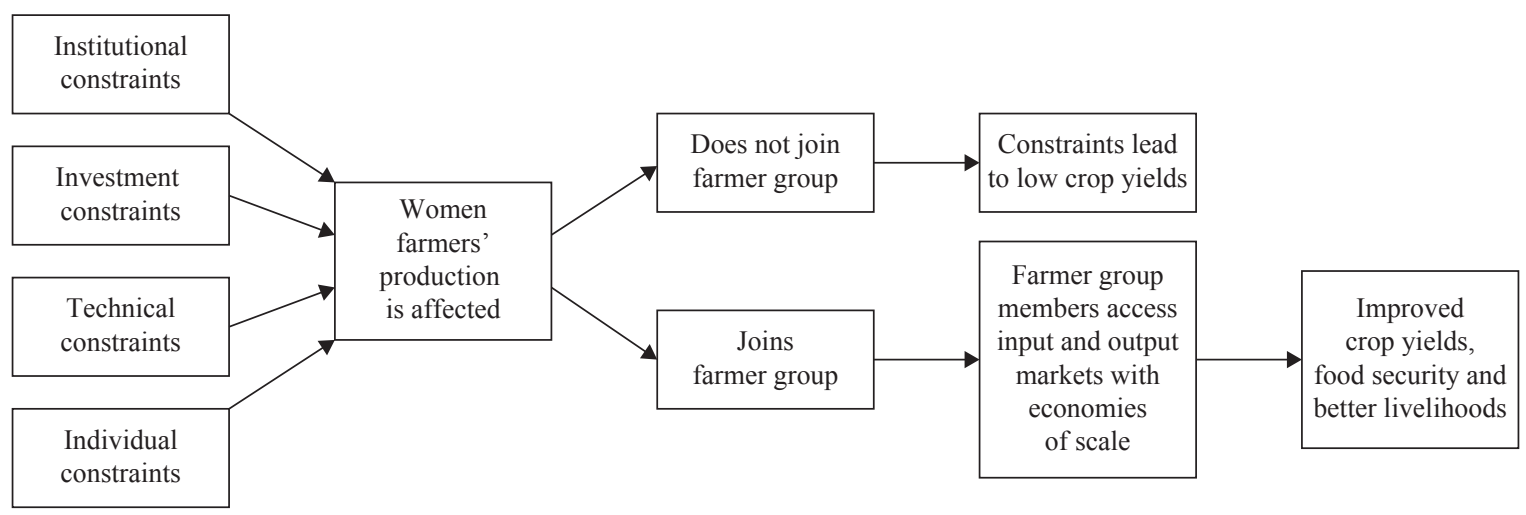

Figure 1. Conceptual framework of women farmers productivity with farmer groups as a platform to boost productivity. 
The literature review points out the numerous challenges female farmers face thereby hindering their effective participation in agriculture, regardless of women's large contribution to crop yields. These contradictory circumstances demand the analysis of the factors affecting women's participation in agriculture. The factors can be specified as:

$$
Y=\beta_{0}+\beta_{i} x_{i}+\varepsilon
$$

where $Y$ is a dependent binary variable ( $Y=1$ for female farmers, $Y=0$ if otherwise), $\beta_{0}$ is the intercept, $\beta_{i}$ represents the regression coefficients that explain the factors affecting female farmers' participation in agriculture, $\chi_{i}$ represents the parameters to be estimated $(i=1,2,3, \ldots)$, and $\varepsilon$ is the error term.

\subsection{Female farmers'membership decisions}

We assume that a female farmer makes a binary decision on whether to participate in a farmer group or not. The probability of participating in a farmer group, holding other things constant will depend on the outcome of the comparison of the expected benefits $\left(G^{*}{ }_{M}\right)$ from participation, and the expected benefits $\left(G^{*}{ }_{N}\right)$ from non-participation. A female farmer's membership decision can be specified as:

$$
\begin{aligned}
& M^{*}=M^{M} \text { if }\left(G^{*}{ }_{M}>G^{*}{ }_{N}\right) \text { or } M^{*}=M^{N} \text { if }\left(G^{*}{ }_{M}<G^{*}\right) \\
& M^{*}=\beta_{0}+\beta_{i} x_{i}+\varepsilon
\end{aligned}
$$

where $M^{*}$ is the membership decision chosen by the farmer (assigned a value of either one or zero), $M^{M}$ represents membership, while $M^{N}$ represents non-membership, $G^{*}{ }_{M}$ are the expected benefits from participation, and $G_{N}^{*}$ are the expected benefits from non-participation, $\beta_{0}$ is the intercept, $\beta_{i}$ represents the regression coefficients that explain the probability of female farmers' participation in farmer groups, $x_{i}$ represents the parameters to be estimated, while $\varepsilon$ is the error term. The probability of participating in a farmer group is specified as:

$$
\operatorname{Pr}\left(M^{*}=M^{M}\right)=\operatorname{Pr}\left(G^{*}{ }_{M}>G^{*}{ }_{N}\right)
$$

Since farmers are generally heterogeneous, not all the female farmers will belong to the farmer groups. However, farmer group participation is expected to be associated with a higher yield, relative to female farmers who are not members of farmer groups. Moreover, the effect of socio-cultural constraints that limit women's access to productive resources is stronger among female farmers that are not members of farmer groups.

\section{Materials and methods}

\subsection{Description of study areas}

Since the survey covers agricultural yields, it was conducted in October 2018 to coincide with the harvesting season (September and October) in the sub-counties of Navakholo (Esumeiya Ward) and Lurambi (Butsotso Central Ward) in Kakamega County, Kenya. Both Lurambi and Navakholo belong to the upper-medium ecological zone. Butsotso Central's population is 25,744 and the land area is $48.8 \mathrm{~km}^{2}$, while Esumeiya's is 25,352 and $48.4 \mathrm{~km}^{2}$, respectively. Small-scale subsistence farming is the main livelihood, carried out on land averaging 1.5 acres in size; the crops include maize, beans, bananas, sugarcane, sweet potatoes, fruits and vegetables, and minimal livestock farming mainly includes dairy cattle and poultry (The County Government of Kakamega, 2013). Numerous, mostly informal farmer groups exist, with poor sustainability measures and no funds. 


\subsection{Model}

\section{- Theoretical model}

Based on figure 1 and the references in the literature review we formulate the following theoretical model:

$$
Y_{i}=\beta_{0}+\beta_{1} X_{1 i}+\beta_{2} X_{2 i}+\beta_{3} F_{3 i} \ldots \ldots+\beta_{7} d_{i}
$$

where $i$ denotes the $i$ th observation in the sample, $P$ is the dependent variable, $\beta_{0}$ is the intercept term and $\beta_{1}, \beta_{2} \ldots \beta_{7}$ are the coefficients associated with the explanatory variables $X_{1}, X_{2} \ldots X_{7}$. We include endogenous binary indicator $F$ for a female farmer being a member of a farmer group.

$Y_{i}=$ Agricultural production of women farmers

$X_{1}=$ Institutional constraints

$X_{2}=$ Investment constraints

$F_{3}=$ Female member of farmer group

$X_{4}=$ Individual constraints

$X_{5}=$ Technical constraints

$X_{6}=$ Access to productive resources

$X_{7}=$ Change in yields

$d_{\mathrm{i}}=$ Regional dummies $d=1, d=0$

The determinants of women farmers' agricultural productivity including institutional, technical, investment and individual are interrelated, with institutional constraints being the starting point. Institutional issues such as social norms limit women's land rights thereby restraining women's collateral to access credit. While gender inequality in education leaves most women illiterate and ignorant (Netsayi et al., 2017). Agricultural extension and information workers tend to bypass women farmers, besides that illiteracy is a barrier to women's adoption of modern agricultural technologies and thus have limited knowledge and training in agribusiness management. Furthermore, cultural norms limit women's decision-making power (Netsayi et al., 2016) and therefore do not participate in crucial agricultural development programs where decisions taken fail to consider gender issues contributing to the high disparity in women's and men's agricultural productivity.

Given that gender norms dictate ownership of assets limits women's potential to invest in more profitable agribusiness of high-value products since women are mostly unable to increase their control over production, income, and assets (Quisumbing et al., 2015). Women's low agricultural productivity due to low investment ability is mostly due to gender inequality in the adoption of technology attributed to unequal access to land, information and other farm inputs exacerbated by gendered patterns of division of agricultural labor, household enterprises and household food consumption decisions (Doss, 2018).

\section{- Analytical model}

A probit model is applied in running empirical regressions, the explanatory variables include farmer group membership $(1=$ member; $0=$ non-member $)$ and household characteristics. We apply an extended probit regression model (eprobit) to evaluate (a) factors affecting female farmers' participation in agriculture and (b) the change in yields after becoming a member of a farmer group. We use extended probit regressions to account for endogenous covariates, treatment and sample selection complications in our estimates. Several studies, including Spielman et al. (2011) and Nkuranga and Wilcox (2013), suggest that farmer groups play a significant role in improving crop yields by facilitating access to productive resources; therefore, farmer group membership is a major factor in positively boosting female farmers' participation in agriculture. On the other hand, low crop yields due to lack of access to productive resources is an incentive for female farmers to join farmer groups. This bidirectional causality between female farmers (dependent variable) and being a female member of a farmer group (independent variable) implies that the disturbance term is correlated with some components of regressors in this case female member of a farmer group is endogenous. The 
presence of endogeneity makes the application of probit estimation yield inconsistent estimates; thus we apply extended probit regression to resolve endogeneity.

The probability of being a female farmer or changes in yield after joining farmer group is $\left(P_{\mathrm{i}}\right)$, while the probability of not being a female farmer or no changes in yield after joining farmer group is $\left(1-P_{\mathrm{i}}\right)$. The eprobit model of the relationship between being a female farmer or changes in yield after joining farmer group (dependent variables) and their explanatory variables based on Equation 5 are specified as:

$$
\left(1-P_{\mathrm{i}}\right)=\beta_{0}+\beta_{1} X_{1 i}+\beta_{2} X_{2 i}+\beta_{3} F_{3 i} \ldots \ldots+\beta_{11} d_{i}
$$

where $P$ is the probability of the outcome, and the rest of the equation remains unchanged.

$P=$ Dependent variables - Female farmer; change in yield after joining farmer group

$X_{1}=$ Information on family planning

$X_{2}=$ Farming is profitable

$F_{3}=$ Female member of farmer group

$X_{4}=$ Marital status

$X_{5}=$ Access to credit before joining farmer group

$X_{6}=$ Land ownership

$X_{7}=$ Mobile phone ownership

$X_{8}=$ Membership years

$X_{9}=$ Irrigation

$X_{10}=$ Non-farm business

$d_{\mathrm{i}}=$ Butsotso Central $d=1$, Esumeiya $d=0$

To answer the question on factors influencing female farmers in making decisions to become members of farmer groups, firstly we use probit regression. Selection bias may arise due to the treated group (farmer group members) differing from the non-treated group (non-members) for reasons other than treatment status. Secondly, we use linear regression with an endogenous treatment model (Woolridge, 2013) to allow for a specific correlation structure between the unobserved reasons that affect the treated group (farmer group members) and the unobserved reasons that affect the potential outcome. The estimation is performed using a maximum likelihood estimator.

The endogenous treatment regression model is composed of an equation for outcome $y_{j}$ and an equation for endogenous treatment $t_{j}$ :

$$
\begin{aligned}
& \sqrt{y_{j}}=\sqrt{x_{j} \beta}+\sqrt{\delta t_{j}}+\varepsilon_{j} \\
& \sqrt{t_{j}}=\left(\begin{array}{l}
1, \text { if } w_{j} \gamma+\mu_{j}>0 \\
0, \text { otherwise }
\end{array}\right)
\end{aligned}
$$

where $x_{\mathrm{j}}$ are covariates used to model the outcome, $w_{\mathrm{j}}$ are covariates used to model treatment assignment, and the error terms $\epsilon_{\mathrm{j}}$ and $u_{\mathrm{j}}$ are a bivariate normal with a mean of zero and a covariance matrix of:

$$
\left[\begin{array}{cc}
\sigma^{2} & \rho^{\sigma} \\
\rho^{\sigma} & 1
\end{array}\right]
$$

The covariates $x_{\mathrm{j}}$ and $w_{\mathrm{j}}$ are unrelated to the error terms, suggesting they are exogenous.

\subsection{Sampling and data collection}

Purposeful sampling was applied for selecting the study areas due to their geographical locations and accessibility. Butsotso Central is situated right next to Kakamega municipality, and farmers were therefore assumed to have easy access to input and output markets along with extension services. On the other hand, Esumeiya is in the interior of the county, further away from both input and output markets. The author that travelled to the survey areas spoke the local language of the regions, an advantage when interacting with the farmers. 
Proportional sampling was used to randomly sample rural small-scale female farmers that were members of farmer groups. The sampling was based on a list of all multi-purpose farmer groups in both study areas, and the number of women per group. A total of 347 smallholder farmers, comprising 137 farmer group members and 210 non-members, were randomly selected and interviewed (female farmers were our target group, however, male farmers responded to the questions in some households) using pre-tested structured questionnaires. Also, leaders of respective farmer groups were interviewed. Our total number of households (347) is representative of the members and non-members of the farmer groups in the areas under study, considering the rule of thumb is having at least 30 observations. Data were gathered on several factors including farm and household characteristics, production and marketing activities along with health, nutritional status, and food security issues. The field survey was conducted with the help of trained research assistants.

\subsection{Data analysis}

Statistical tools employed include descriptive statistics (Excel data analysis (Microsoft Excel, Microsoft, Redmond, WA, USA)) and econometric analysis with the help of the STATA software package (StataCorp LLC, College Station, TX, USA). Table 2 presents the definition and summary statistics of variables used in empirical analysis. Table 2 indicates that, on average, a farmer in the sample is about 42 years old and has about 8 years of formal education. Of the farmers in the sampled population, $69 \%$ are women and $31 \%$ of the female farmers participate in farmer groups. They cultivate 1.5 ha and increased their crop intensity after joining a farmer group by $53 \%$, leading to $85 \%$ higher crop yields. Of the female farmers, $58 \%$ confirmed that farming is profitable, and only $42 \%$ had received information about the importance of family planning. Family planning questions were based on the benefits of family planning; the knowledge of respondents was tested by answering true or false questions. The variable on food safety storage is an average of the questions on perishable and cooked food storage practices. While market information is the responses to whether respondents receive market information and have easy access to markets.

Table 2. Variable definition and summary statistics.

\begin{tabular}{|c|c|c|c|}
\hline Variable & Definition & Mean & Std. Dev. ${ }^{1}$ \\
\hline Respondent_age & Age of respondent (years) & 41.95 & 14.65 \\
\hline Female group member & 1 if female farmer participates in farmer group, 0 otherwise & 0.31 & 0.46 \\
\hline Female farmer & 1 if farmer is female, 0 otherwise & 0.69 & 0.73 \\
\hline Youth & 1 if youth (18-35 years), 0 otherwise & 0.39 & 0.49 \\
\hline Average household size & The average of household size & 4.80 & 2.17 \\
\hline Education & Education respondent (years) & 7.50 & 4.15 \\
\hline Land ownership & 1 if the family owns land, 0 otherwise & 0.96 & 0.19 \\
\hline Total farm land & Total farmland under family's control (hectares) & 1.50 & 1.13 \\
\hline Farming profitable & 1 if farming is profitable, 0 otherwise & 0.58 & 0.94 \\
\hline Food safety storage & Average $(\%)$ food safety - clean, separate, cook, storage & 34.35 & 23.71 \\
\hline Timely payment of production & 1 if farmer groups pay farmers in time, 0 otherwise & 0.27 & 0.45 \\
\hline Nonfarm business & 1 if farmer is involved in non-farm business, 0 otherwise & 0.56 & 0.50 \\
\hline Market information & 1 if farmer receives market information, 0 otherwise & 0.45 & 0.75 \\
\hline Farming decisions & 1 if farming decisions are not made by self, 0 otherwise & 0.69 & 0.47 \\
\hline Electricity access & 1 if farmer has access to electricity, 0 otherwise & 0.36 & 0.48 \\
\hline Access to credit & 1 if farmer has access to credit, 0 otherwise & 0.32 & 0.47 \\
\hline Information family planning & 1 if farmer has ideas about family planning, 0 otherwise & 0.42 & 0.34 \\
\hline$\%$ change in crop intensity & $\%$ change in crop intensity after joining farmer group & 52.62 & 58.97 \\
\hline$\%$ change in yield & $\%$ change in crop yield after female F. joint farmer group & 85.42 & 141.66 \\
\hline$\%$ change in income & $\%$ change in income after female farmer joined farmer group & 189.20 & 219.61 \\
\hline Butsotso Central & 1 if farmer is in Butsotso Central, 0 otherwise & 0.41 & 0.49 \\
\hline Esumeiya & 1 if farmer is in Esumeiya, 0 otherwise & 0.59 & 0.49 \\
\hline
\end{tabular}

${ }^{1}$ Std. Dev. $=$ standard deviation. 
Given that our dependent variables are dummy variables (categorical, coded as 0,1 ) fails to fulfil a key implicit assumption in ordinary least squares (OLS) regression that requires the dependent variable to be continuous. Furthermore, a great concern for purposes of interpretation is that the predicted probabilities of OLS can be greater than 1 or less than 0 , which can be a problem for subsequent analysis. Probit models are estimated with maximum likelihood estimation, not with OLS so the standard problem with heteroskedasticity does not apply to the probit model. That is why we have chosen a probit model as a suitable analytical tool.

In Table 3 standardised Beta coefficients were used to obtain the combined effects of the independent variables on the dependent variable because they allow the comparison of relative effects of predictors measured on different scales (Bryman and Cramer, 2009; Nieminen et al., 2013). While in Table 5 marginal effects were computed to allow for a better interpretation of the results (Greene, 2012).

\section{Results and discussion}

\subsection{Factors affecting female farmers 'participation in agriculture}

Table 3 presents estimates of the factors affecting female farmers' participation in agriculture. The benefits of being a member of a farmer group, such as the creation of social relationships, that enable female farmers to achieve goals that they may not otherwise be able to achieve by themselves are evident through the estimate for female farmer membership in a farmer group, which is statistically significant at the 0.01 level. Furthermore, a 1-unit increase in female farmer membership in a farmer group increases women's participation in agriculture by 1.8 units. This is consistent with the finding by Quisumbing and Pandolfelli (2010) who report that farmer organisations are feasible mechanisms that enable resource-poor women to achieve economies of scale by lowering the costs of acquiring inputs or hiring services such as farm machinery, transport or storage.

Table 3. Factors affecting female farmer's participation in agriculture. ${ }^{1}$

\begin{tabular}{|c|c|c|c|c|}
\hline Dependent variable: female farmer & Beta coefficients & Std. Err. ${ }^{2}$ & $\mathrm{Z}$ scores & $P$-value \\
\hline Constant & 0.056 & 0.323 & 0.17 & 0.862 \\
\hline Farming decision not made byself & $-1.182 * * *$ & 0.197 & -6.00 & 0.000 \\
\hline Female farmer group member & $1.823^{* * *}$ & 0.541 & 3.37 & 0.001 \\
\hline Information on family planning & $0.614 * *$ & 0.245 & 2.51 & 0.012 \\
\hline Farming profitable & $0.351^{* *}$ & 0.171 & 2.06 & 0.039 \\
\hline Access to credit before group membership & $-1.041 * *$ & 0.493 & -2.11 & 0.035 \\
\hline Marital status & $-0.229 * *$ & 0.105 & -2.19 & 0.028 \\
\hline Land ownership & $0.779 * *$ & 0.343 & 2.27 & 0.023 \\
\hline Butsotso Central & -0.097 & 0.176 & -0.55 & 0.580 \\
\hline \multicolumn{5}{|l|}{ Treatment variable: female group member } \\
\hline Constant & $-1.128 * * *$ & 0.162 & -6.95 & 0.000 \\
\hline Collateral requirement & $1.118^{* * *}$ & 0.324 & 3.44 & 0.001 \\
\hline Farmer group's good price for produce & $1.163 * * *$ & 0.312 & 3.73 & 0.001 \\
\hline Farming decision not made byself & $-0.600 * * *$ & 0.182 & -3.29 & 0.001 \\
\hline Butsotso Central & $0.521 * * *$ & 0.176 & 2.97 & 0.003 \\
\hline Corr. (e.female groupmember, e.female farmer) & $0.636 * * *$ & 0.139 & 4.59 & 0.000 \\
\hline $\mathrm{ATE}^{2}$ : female group member & 0.384 & 0.054 & 7.00 & 0.000 \\
\hline $\mathrm{ATET}^{2}$ : female group member & 0.273 & 0.054 & 5.08 & 0.000 \\
\hline Number of observations & 347 & & & \\
\hline
\end{tabular}


Female farmers need to participate in vital decision-making in farming, including the kind of crops grown, the purchase and application of farm inputs, the marketing of farm products and how to utilise the proceeds. Social-cultural factors that limit women's participation in decision-making negatively affects women's participation in agriculture. Moreover, Table 3 shows that the estimate for farming decisions not made by female farmers is statistically significant at the 0.01 level, a 1 -unit increase in farming decisions not made by female farmers decreases women's participation in agriculture by 1.2 units.

Generally, farmer groups tend to obtain higher prices for marketed products and lower prices for purchased products. Individually, female farmers, in particular, have little influencing power, but as part of farmer groups, their collective action increases the market price of their products. Moreover, results in Table 3 show that the estimate for farmer groups' good prices for farm products is statistically significant at the 0.01 level. Furthermore, a 1-unit increase in farmer groups' good prices for farm products increases female farmers' participation in agriculture by 1.2 units, which is consistent with the finding of Bernard et al. (2008b) and Fischer and Qaim (2012).

Low birth interval negatively affects the health of both the mother and child; mothers under these circumstances are depleted, spending more time nursing the sickly underweight children and having no energy to participate in agriculture. The estimate information on family planning is statistically significant at the 0.10 level, furthermore, a 1-unit increase in information on family planning increases women's participation in agriculture by 0.61 units. Table 2 indicates that only $42 \%$ of the female farmers have received information on family planning.

Table 1 indicates that only 7\% of the women in Kenya owned land during the period 2000-2018. Table 3 shows the estimate for land ownership is statistically significant at the 0.10 level, furthermore, a 1-unit increase in women owning land increases women's participation in agriculture by 0.77 units. Presently, as pointed out above, women are allocated a piece of land by their husbands, but women have no control over the allocated land, for instance, to use it as collateral in obtaining credit.

Table 3 shows the correlation between female membership in a farmer group and female farmer (the dependent variable) is 0.64 , implying they are endogenous; the more female farmers join farmer groups the more they become effective participants in agriculture. The average treatment effects (ATE) is the average of the difference between female farmers when each female farmer is a member of a farmer group (the treated) and female farmers when none of the female farmers are members of a farmer group (control group). The results of ATE in Table 3 show that if all female farmers were members of farmer groups the number of female farmers' effective participation in agriculture would increase by 0.38 units. The causal effect among female farmers who are farmer group members, known as the average treatment effect on the treated or ATET, has increased by 0.27 units in Table 3 .

Table 4 presents estimates of the factors influencing a female farmer's decision to participate in a farmer group. We find that the decision to participate in a farmer group is positively and significantly influenced by accessibility to sufficient credit. Farmer groups with credit facilities increase female farmers' probability to participate in farmer groups by $47 \%$, as revealed by the marginal effect. Lack of collateral (usually land) has constrained women from accessing credit facilities. Microfinance lending institution services are more accessible to rural women because they charge lower interest rates than money lenders and mostly replace collateralised loans with peer-supported guarantees of group lending, whereby becoming a member of a farmer group facilitates access to credit (Ingutia, 2017). Farmers with access to credit are not only enabled to fulfil their group obligations, including membership fees and periodic cash contributions, but they can also procure production inputs such as farm equipment, fertiliser and chemicals as well as pay for labour expenses.

As noted in Section 2.1, the land is the most valuable asset in most rural households' portfolios; it is the key collateral in obtaining credit, and yet female farmers have limited access to land. In Table 4a, we find that the estimate for not owning land is statistically significant with a negative effect. Additionally, it has about 
Table 4a. Probit model estimates of factors influencing female farmer's decision to participate in farmer group. ${ }^{1}$

\begin{tabular}{|c|c|c|c|c|}
\hline \multirow[t]{2}{*}{ Dependent variable: Female group member } & \multicolumn{2}{|c|}{ Probit coefficients } & \multicolumn{2}{|c|}{ Marginal effects } \\
\hline & Coefficients & Std. Err. ${ }^{2}$ & Coefficients & Std. Err. $^{2}$ \\
\hline Constant & $-0.759 *$ & 0.452 & & \\
\hline Access to credit after group membership & $1.566 * * *$ & 0.308 & $0.470 * * *$ & 0.094 \\
\hline Education & $-0.059 * *$ & 0.026 & $-0.015 * *$ & 0.007 \\
\hline Land ownership & $-0.709 * *$ & 0.444 & $-0.227 *$ & 0.164 \\
\hline Membership years & $0.157 * * *$ & 0.039 & $0.039 * * *$ & 0.010 \\
\hline Market access & $-1.144 * * *$ & 0.311 & $-0.288 * * *$ & 0.073 \\
\hline Farming decision & $-0.648 * * *$ & 0.232 & $-0.173 * *$ & 0.064 \\
\hline Collateral requirement & $0.807 * * *$ & 0.295 & $0.237 * *$ & 0.096 \\
\hline Extension visit & $0.563 * *$ & 0.258 & $0.148 * *$ & 0.069 \\
\hline Butsotso Central & $0.921 * * *$ & 0.228 & $0.247 * * *$ & 0.062 \\
\hline $\mathrm{R}^{2}$ & 0.57 & & & \\
\hline Number of observations & 347 & & & \\
\hline
\end{tabular}

Table 4b. Linear regression with endogenous treatment. estimator maximum likelihood. ${ }^{1}$

\begin{tabular}{lcccc}
\hline Dependent variable: Female group member & Coefficients & Std. Err. $^{2}$ & Z scores & $\boldsymbol{P}_{\text {-value }}$ \\
\hline Constant & $0.169^{* * *}$ & 0.095 & 1.78 & 0.076 \\
Access to credit after group member & $0.390^{* * *}$ & 0.064 & 6.12 & \\
Education & $-0.008^{* *}$ & 0.004 & -2.13 & 0.033 \\
Land ownership & $-0.282^{* * *}$ & 0.096 & -2.96 & 0.003 \\
Membership years & $0.032^{* * *}$ & 0.007 & 4.38 & 0.000 \\
Market access & $-0.147^{* * *}$ & 0.038 & -3.85 & 0.000 \\
Farming decision & $-0.059^{* *}$ & 0.033 & -1.80 & 0.072 \\
Collateral requirement & $0.175^{* * *}$ & 0.057 & 3.05 & \\
Extension visit & $0.599^{* * *}$ & 0.064 & 9.43 & 0.000 \\
Butsotso Central & $0.141^{* * *}$ & 0.043 & 3.28 & 0.001 \\
\hline Treatment variable: Extension visit & & & & \\
\hline Constant & $-1.337^{* * *}$ & 0.325 & -4.11 & 0.000 \\
Land ownership & $0.802^{* *}$ & 0.325 & 2.47 & 0.014 \\
Respondent gender & $0.643^{* * *}$ & 0.114 & 5.63 & 0.000 \\
Butsotso Central & -0.067 & 0.135 & -0.50 & 0.619 \\
Number of observations & 347 & & & \\
athrho & -1.316 & 0.159 & -8.29 & 0.000 \\
Sigma & 0.385 & 0.024 & & \\
lambda & -0.334 & 0.034 & & \\
\hline
\end{tabular}

$1 *, * *, * * *$ represent significance at 10,5 and $1 \%$ levels respectively.

2 Std. Err. $=$ standard error.

a $23 \%$ probability of influencing female farmers' decision to not participate in farmer groups that require land ownership for membership, Meinzen-Dick et al. (2017) also found land to be an invaluable asset.

Women's farming decisions not being able to be made by themselves exert a negative and significant effect on women's decision to participate in farmer groups. Women's limited participation in decision-making 
decreases their probability to participate in a farmer group by $17 \%$. Women's limited representation in leadership positions (Table 1) has largely contributed to their needs not receiving the due attention in policy and resource allocation. However, farmer groups create an enabling environment for farmers through collective bargaining power in input and output markets and active participation in decision-making from the grassroots to policy formulation to access services at more affordable prices, thereby reducing costs and increasing yields, sales, and profits (Elbehri and Lee, 2011).

Table 4a results indicate that relative to Esumeiya (reference district), farmers located around the Butsotso Central district have about a $0.92 \%$ probability of participating in farmer groups. These findings suggest that location fixed effects also influence farmers' decisions to participate in farmer groups.

Endogeneity, treatment and sample selection bias issues may arise, for instance, people who seek extension services are mostly the older and more educated households with access to credit and extension services; this same set of people are more likely to become farmer group members (Wossen et al., 2017). Not all female farmers are facing constraints, there could be some older and more educated female farmers with access to credit and extension services who are more likely to be farmer group members than non-members. This set of female farmers' decisions to participate in farmer groups is influenced by factors other than the benefits associated with joining farmer groups (treatment status). To correct for endogeneity and selection bias issues, we use maximum likelihood to estimate the parameters of linear regression with endogenous treatment effects (Table 4b). We note that the probit model (Table 4a) coefficients' values are far higher than the selection model coefficients for maximum likelihood (Table 4b), the only exception is the estimated coefficient of extension visit, which is 0.563 in Table $4 \mathrm{a}$ and has increased to 0.569 in Table $4 \mathrm{~b}$. These findings suggest that the maximum likelihood estimator using endogenous treatment effects has corrected for endogeneity and selection bias, thus producing more consistent results.

Table 5 presents estimations of the percentage change in crop yields after female farmers joined a farmer group, we apply the extended probit regression model as mentioned in Section 3.2. We find that female farmers' membership years in a farmer group contributes to the percentage change in yields. The estimate for membership years is statistically significant at the 0.05 level, furthermore, a 1-unit increase in membership years has the probability of increasing crop yield by $0.14 \%$. These results suggest that higher yields can be associated with the benefits of membership years in farmer groups including easy access to credit, farm inputs, information, and extension services, among others. A similar finding is reported in other studies (Mwaura, 2014).

Mobile phone ownership has the transformative potential to improve the crop yields of female farmers in Kenya because those without bank accounts can now receive money transfers on their mobile phones through M-PESA (mobile banking service). Moreover, farmers can now have access to crop prices, be connected to buyers and sellers and receive weather alerts through mobile phones. In Table 5, the estimate for having a mobile phone is statistically significant at the 0.01 level, a 1-unit increase in mobile phone holders has the probability of increasing crop yields by $2.4 \%$; Krell et al. (2020) and Baumuller (2015) had similar findings. The estimate for being a female member of a farmer group lost statistical significance in explaining changes in crop yield after joining a farmer group because of the presence of the estimate for membership years and having a mobile phone since mobile phone status facilitates access to services such as information that are mostly accessed through farmer groups.

Lack of access to credit has been depicted in Table 3 as a significant factor affecting female farmers' effective participation in agriculture, while Table 4 indicates access to credit is a crucial factor influencing female farmers' decisions to participate in agriculture. The same theme is carried on in Table 5, where the estimate for lack of access to credit before joining a farmer group is statistically significant at the 0.01 level. A 1-unit increase in the number of female farmers without access to credit has the probability of decreasing crop yield by $1.4 \%$. 
Table 5. Extended probit regression of percentage change in crop yields after joining farmer group. ${ }^{1,2}$

\begin{tabular}{|c|c|c|c|c|}
\hline Dependent variable: Change in yields & Coefficients & Std. Err. ${ }^{3}$ & $Z$ scores & $P$-value \\
\hline Constant & -0.325 & 0.957 & -0.01 & 0.990 \\
\hline Mobile phone & $2.385 * * *$ & 0.489 & 4.87 & 0.000 \\
\hline Membership years & $0.139 * *$ & 0.060 & 2.31 & 0.021 \\
\hline Lack access to credit before group member & $-1.413 * *$ & 0.567 & -2.49 & 0.013 \\
\hline Irrigation & $1.067 * *$ & 0.521 & 2.05 & 0.041 \\
\hline Nonfarm business & $-0.656 * *$ & 0.360 & -1.82 & 0.069 \\
\hline Farm machinery & $-1.985^{* *}$ & 0.805 & -2.46 & 0.014 \\
\hline Female group member & 1.555 & 0.946 & 0.01 & 0.990 \\
\hline Butsotso Central & -0.388 & 0.372 & -0.01 & 0.990 \\
\hline \multicolumn{5}{|l|}{ Treatment-endogenous: Female group member } \\
\hline Constant & $-1.366^{* * *}$ & 0.201 & -6.81 & 0.000 \\
\hline Collateral requirement & $2.235 * * *$ & 0.223 & 10.02 & 0.000 \\
\hline Strategies for food security & $0.611 * * *$ & 0.204 & 2.99 & 0.003 \\
\hline Farming decision & $-0.441 * *$ & 0.186 & -2.37 & 0.018 \\
\hline Market accessibility & $-0.769 * * *$ & 0.237 & -3.24 & 0.001 \\
\hline Butsotso Central & $1.366^{* * *}$ & 0.201 & 6.81 & 0.000 \\
\hline Corr. (e. female group member. e. change in yields) & -0.515 & 0.392 & -1.31 & 0.189 \\
\hline $\mathrm{ATE}^{3}$ & 0.275 & 0.071 & 3.90 & 0.000 \\
\hline ATET $^{3}$ & 0.328 & 0.057 & 5.73 & 0.000 \\
\hline Number of observation & 347 & & & \\
\hline
\end{tabular}

Table 5 indicates that the estimate of the correlation between the errors of the two equations (change in yields and female member of farmer group) is -0.51 and is significantly different from zero, implying there is endogeneity. Since the correlation is negative, we conclude that the unobservable factors that decrease the number of female farmers that are members of farmer groups also decrease crop yield. The results of the ATE in Table 5 show that if all female farmers were members of farmer groups the change in crop yield could increase by $27 \%$, while the ATET of change in crop yield has increased by $33 \%$.

Figure 2 depicts percentage changes in crop yields of female farmers after joining a farmer group ranging from $85-684 \%$. The wide disparity can partly be attributed to female farmers being heterogeneous (e.g.

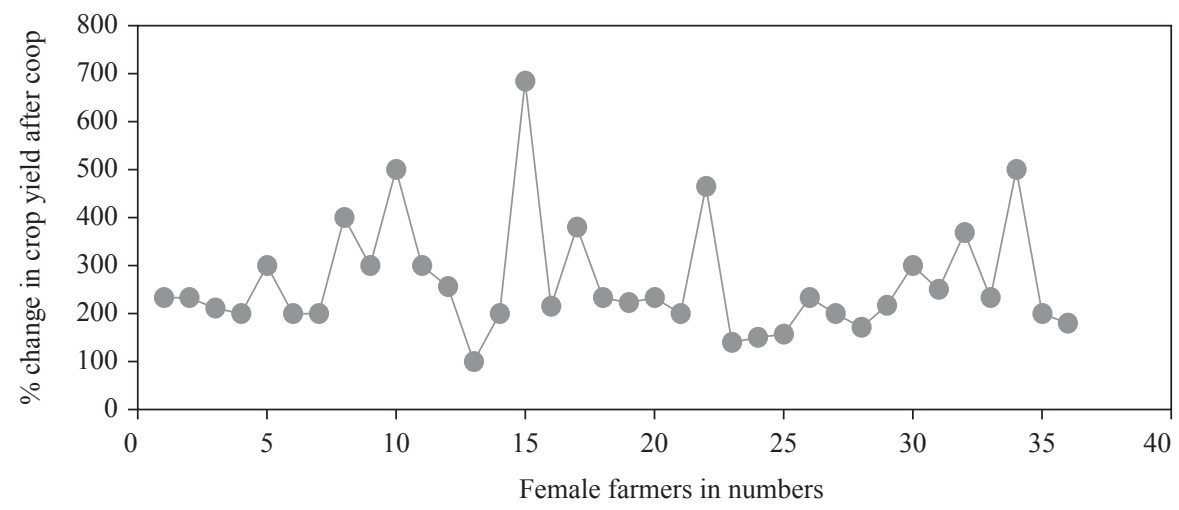

Figure 2. Percentage change in crop yield after joining farmer group. 
social-economic status), therefore the impact of farmer group on situations of respective female farmers varies. Table 6 compares the socio-economic status of members and nonmembers of farmers groups to gauge if farmer groups make agribusiness more productive in the area under study. To minimise the biases that may arise by simply comparing members and non-members, we use Fisher's exact test and Mann-Whitney $\mathrm{U}$ test to test for any statistically significant differences between the two groups.

$t$-test comparison of the means of members and non-members, suggests that farmer groups make agribusiness more productive. Fisher's exact $P$-value indicates that members of farmer groups are not identical (evidenced by statistically significant differences) to non-members in crucial factors contributing to production including: (a) education which is crucial to enable farmers to participate in training in modern agricultural technologies; (b) access to extension visit services a platform for both training farmers and for providing farm inputs; (c) market information including better input and output market prices essential for agribusiness.

\section{Conclusions}

This study began by investigating the factors that affect women's participation in agriculture, followed by factors influencing the decision of female farmers in joining farmer groups. Finally, the role of farmer groups in improving women's crop yield was analysed. This was done using recent primary data of 347 farmers from the districts of Esumeiya and Butsotso Central in Kakamega County, Kenya. We used extended probit and maximum likelihood (endogenous treatment) for running regressions, with endogeneity, treatment and sample selection complications being accounted for. The empirical results revealed that membership

Table 6. $t$-test comparison of the means of members and non-members. ${ }^{1}$

\begin{tabular}{|c|c|c|c|c|c|c|}
\hline \multirow[t]{2}{*}{ Variables } & \multicolumn{2}{|c|}{ Member } & \multicolumn{2}{|c|}{ Nonmember } & \multicolumn{2}{|l|}{ Difference } \\
\hline & Mean & Std. Dev. ${ }^{2}$ & Mean & Std. Dev. ${ }^{2}$ & Pearson's & Fisher's \\
\hline Respondent_age & 41.63 & 12.37 & 42.19 & 16.01 & & \\
\hline Illiteracy & 0.17 & 0.38 & 0.23 & 0.42 & 0.136 & 0.175 \\
\hline Education & 7.53 & 3.76 & 7.48 & 4.40 & 0.015 & 0.015 \\
\hline Youth & 0.36 & 0.48 & 0.41 & 0.49 & 0.436 & 0.499 \\
\hline Average household size & 4.90 & 2.02 & 4.80 & 2.27 & 0.365 & 0.349 \\
\hline Land ownership & 0.99 & 0.12 & 0.95 & 0.23 & 0.065 & 0.084 \\
\hline Land use & 0.98 & 0.15 & 0.95 & 0.23 & 0.152 & 0.175 \\
\hline Farmsize hectares & 1.49 & 1.14 & 1.51 & 1.13 & 0.743 & 0.772 \\
\hline Farming profitable & 0.62 & 1.14 & 0.56 & 0.88 & 0.869 & 0.915 \\
\hline Without food & 0.91 & 0.29 & 0.92 & 0.28 & 0.831 & 0.835 \\
\hline Butsotso Central & 0.58 & 0.50 & 0.36 & 0.48 & 0.000 & 0.000 \\
\hline Esumeiya & 0.46 & 0.50 & 0.64 & 0.48 & 0.003 & 0.004 \\
\hline Nonfarm business & 0.60 & 0.49 & 0.54 & 0.50 & 0.251 & 0.269 \\
\hline Extension visit & 0.50 & 0.50 & 0.36 & 0.48 & 0.011 & 0.014 \\
\hline Market information & 0.49 & 0.50 & 0.42 & 0.88 & 0.065 & 0.038 \\
\hline Farming decisions & 0.64 & 0.48 & 0.71 & 0.45 & 0.189 & 0.215 \\
\hline Food safety storage & 38.80 & 26.54 & 31.20 & 21.07 & 0.043 & 0.044 \\
\hline Electricity access & 0.44 & 0.50 & 0.31 & 0.46 & 0.012 & 0.016 \\
\hline Membership years & 5.35 & 3.31 & & & 5.38 & 3.31 \\
\hline$\%$ change in yield & 85.42 & 141.66 & & & 85.42 & 141.66 \\
\hline Info family plan & 0.50 & 0.33 & 0.37 & 0.34 & 0.001 & 0.001 \\
\hline
\end{tabular}

${ }^{1}$ Land ownership in this study is at household level data, because a majority of the women interviewed affirmed that they had land in the sense that they were allocated a small portion of the land by their husbands to farm. However, they have no control over the land, they cannot use it as collateral to get credit.

${ }^{2}$ Std. Dev. = standard deviation. 
in a farmer group and women owning land increases women's effective participation in agriculture, while women's limited power in decision-making in farming issues and lack of access to credit decreases women's effective participation in agriculture.

The results suggest that farmer groups with easy access to credit largely influence women's decisions in joining farmer groups. Conversely, sociocultural factors, including women not owning land and limited decision-making power, mostly dissuades women from participating in farmer groups. Location fixed effects also influence farmers' decisions to participate in farmer groups. Empirical results indicate that female farmers' membership years in a farmer group have a positive significant effect on the percentage change in yields. Furthermore, possession of a mobile phone enables money transfers, access to crop prices and other essential information, thereby contributing to increased crop yields. The theme of the critical role of access to credit has been shown in it significantly affecting female farmers' effective participation in agriculture, in its influencing female farmers' decisions to participate in agriculture and in determining changes in crop yields.

Some policy implications and agrobusiness management implications can be drawn from the findings of this study. The results revealed that membership years had a positive impact on crop yields, Awal and Abdulai (2018) had similar findings. Members of farmer groups incur reduced transaction costs due to having access to extension services including training and market information leading to better input and output prices, these benefits boost agrobusiness management. Getnet et al. (2018) are of the same opinion. The results suggest that farmer groups are particularly effective platforms to improve crop yields and other multiple constraints confronting female farmers, Ingutia (in press) had similar conclusions. If farmer groups get support from the government, they can: (a) give credit to women to facilitate women's access to land and other productive resources; (b) develop input supplying and product collecting and marketing cooperatives thereby upgrading agrobusiness management.

The situation of female farmers as described in Section 2.1 is likely to diminish through effective and efficient farmer groups because the latter is a common platform for female farmers as beneficiaries and governments, donor agencies and agribusiness companies as benefactors targeting the promotion of smallholder productivity. Surprisingly, the farmer group platform is largely under-utilised, particularly in rural Kenya, evidenced by only $31 \%$ of the female farmers participating in farmer groups (Table 2) as well as the multiple constraints female farmers face, and yet the literature indicates the potential of farmer groups in reducing these constraints.

It is through farmer groups that illiterate women can, for example, receive adult education, obtain essential information on family planning and nutrition education, become empowered in decision-making, receive extension services. Most farmer groups in rural areas do not offer any of these services to their members because of unskilled management, lack of capital, corrupt practices and lack of commitment from both members and the management. It is worth noting that the few agricultural cooperatives available in rural Kenya have similar challenges as farmer groups. The only notable differences are cooperatives' legal status, size of membership and being mostly commercial farming. The empirical results support the transformation of farmer groups from being mainly associated with access to credit to needs-based community-related services (education, family planning, gender equality). Policymakers should invest in the human, financial and physical capital of farmer groups because it is a pathway to rural development, improvement of rural livelihoods and reducing poverty.

\section{Financial support}

Kyösti Haataja Foundation.

\section{Conflict of interest}

The authors have no conflict of interest. 


\section{References}

Adekunle, O.O. 2013. Analysis of effectiveness of agricultural extension service among rural women: a case study of Odeda Local Government Ogun State Nigeria. Journal of Agricultural Science 5(12): 65-71.

Ainembabazi, J.H., P. Van Asten, B. Vanlauwe, E. Ouma, G. Blomme, E.A. Birachi, P.M.D. Nguezet, D.B. Mignouna and V.M. Manyong. 2017. Improving the speed of adoption of agricultural technologies and farm performance through farmer groups: evidence from the Great Lakes Region of Africa. Agricultural Economics 48(2): 241-259.

Akombi, J.B., K.E. Agbo, D. Merom, A.M. Renzabo and J.J. Hall. 2017. Child malnutrition in sub Saharan Africa: a meta-analysis of demographic and health surveys (2006-2016). PLoS ONE 12(5): e0177338. https://doi.org/10.1371/journal.pone.0177338

Asiedu, C. 2012. Information, communication technologies for gender and development in Africa. The case for radio and technological blending. International Communication Gazette 74(3): 240-257.

Awal, R.B. and A. Abdulai. 2018. Do farmer groups impact on farm yields and efficiency of smallholder farms? Evidence from rice farmers in Northern Ghana. Food Policy 81: 95-105.

Banthia, A., S. Johnson, M. McCord and B. Matthews. 2009. Micro-insurance that works for women: making gender-sensitive microinsurance programs. Microinsurance Paper No. 3, Microinsurance Innovation Facility. International Labor Organization, Geneva, Switzerland.

Barret, C.B., M.E. Bachke, M.F. Bellemare, H.C. Michelson, S. Narayanan and T.F. Walker. 2012. Smallholder participation in contract farming: comparative evidence from five countries. World Bank, Washington, DC, USA.

Baumuller, H. 2015. Assessing the role of mobile phones in offering price information and market linkages: the case of M-Farm in Kenya. The Electronic Journal of Information Systems in Developing Countries 68(1): 1-16.

Beegle, K., L. Christiaensen, A. Dabalen and I. Gaddis. 2016. Poverty in a rising Africa. World Bank, Washington, DC, USA. Available at: https://openknowledge.worldbank.org/handle/10986/22575

Bernard, T., A. De Janvry and E. Sadoulete. 2008a. Do village organizations make a difference in African rural development? A study for Senegal and Burkina Faso. World Development 36(11): 2188-2204.

Bernard, T., A.S. Taffesse and E. Gabre-Madhin. 2008b. Impact of cooperatives on smallholders' commercialization behavior: evidence from Ethiopia. Agricultural Economics 39(2): 147-161.

Bibby, A. and L. Shaw. 2005. Making a difference: cooperative solution to global poverty. Cooperative College for the Department of International Development, Manchester, UK.

Birchall, J. and R. Simmons. 2009. Cooperatives and poverty reduction evidence from Sri Lanka and Tanzania. Cooperative College for the Department of International Development, Manchester, UK.

Bobonis, G.J. 2009. Is the allocation of resources within the household efficient? New evidence from a randomised experiment. Journal of Political Economy 117(3): 453-503.

Bryman, A. and D. Cramer. 2009. Quantitative data analysis with SPSS 14, 15 \& 16 a guide for social scientists. Routledge, New York, NY, USA.

Chamala, S. and P.M. Shingi. 1996. Improving agricultural extension. A reference manual: chapter 21. Establishing and strengthening farmer organizations. FAO, Rome, Italy.

Chinyophiro, A. 2017. Gender in food and nutrition security: towards attaining the right to food. UN Women, IFAD, WFP Expert Group Meeting - 'Challenges and opportunities in achieving gender equality and the empowerment of rural women and girls'. 20-22 September 2017. Rome, Italy.

Davis, B., S. Di Guiseppe and A. Zezza. 2017. Are African households (not) leaving agriculture? Patterns of households' income sources in rural sub-Saharan Africa. Food Policy 67: 153-174.

Doss, C.R. 2018. Women and agricultural productivity: reframing the issues. Development Policy Review 36: $35-50$.

Duguid, F. and N. Weber. 2016. Gender equality and women's empowerment in cooperatives: a literature review. International Cooperative Alliance, Brussels, Belgium.

Elbehri, A. and M. Lee. 2011. The role of women producer organizations in agricultural value chains: Practical lessons from Africa and India. FAO, Rome, Italy. 
Fischer, E. and M. Qaim. 2012. Linking smallholders to markets: determinants and impacts of farmer collective action in Kenya. World Development 40(6): 1255-1268.

Fischer, T., D. Byerlee and G. Edmeades. 2014. Crop yields and global food security: will yield increase continue to feed the world? The Australian Centre for International Agricultural Research (ACIAR), Bruce, Australia.

Fletschner, D. 2009. Rural women's access to credit: market imperfections and intra-household dynamics. World Development 37(3): 618-631.

Fletschner, D. and L. Kenney. 2011 Rural women's access to financial services credit, savings and insurance. ESA Working Paper No. 11. Agricultural Development Economics Division, FAO, Rome, Italy.

Floro, M. 2002. Mobilizing domestic resources for development: through the lens of poor women. Paper presented at the Conference on Gender Budgets, Financial Markets, Financing for Development. Heinrich Böll Foundation, Berlin, Germany.

Food and Agriculture Organization (FAO). 1995, Women, agriculture and rural development in a synthesis report of the Africa region. Economic and Social Development Department, FAO, Rome, Italy.

Food and Agriculture Organization (FAO). 2005. Contribution of farm power to smallholder livelihoods in sub Saharan Africa. FAO, Rome, Italy.

Food and Agriculture Organization (FAO). 2011. The state of food and agriculture: women in agriculture, closing the gender gap for development. FAO, Rome, Italy.

Food and Agriculture Organization (FAO). 2012. Cooperatives: empowering women farmers, improving food security. FAO, Rome, Italy.

Food and Agriculture Organization (FAO). 2018a. The state of food security and nutrition in the world: building climate resilience for food security and nutrition. FAO, Rome, Italy.

Food and Agriculture Organization (FAO). 2018b. Crop prospects and food situation. Quarterly Global Report. FAO, Rome, Italy.

Food and Agriculture Organization / International Fund for Agricultural Development / United Nations International Children's Emergency Fund / UN World Food Programme / World Health Organization (FAO/IFAD/UNICEF/WFP/WHO). 2019. The state of food security and nutrition in the world 2019. Safeguarding against economic slowdowns and downturns. FAO, Rome, Italy.

Getnet, K., G. Kefyalew and W. Berhanu. 2018. On the power and influence of the cooperative institution: does it secure competitive producer prices? World Development Perspectives 9: 43-44.

Greene, W.H. 2012. Econometric analysis. Prentice Hall, Hoboken, NJ, USA.

Grist, N. 2014. Transformativeadaptation in Africa's agriculture. Contribution note for Africa progress panel meeting. Expert consultation: an African agenda for green, low carbon development. October 30, 2014. Geneva, Switzerland.

Hill, C. 2011. Enabling rural women's economic empowerment: institutions, opportunities and participating. UN Women in Cooperation with FAO, IFAD and WFP Expert Group Meeting. FAO, Rome, Italy.

Ingutia, R. 2017. Factors affecting child poverty in sub Saharan Africa revisited with special reference to education and rural women 1990-2010. Doctoral thesis, University of Helsinki, Helsinki, Finland.

Ingutia, R. in press. The Impacts of COVID-19 and climate change on smallholders through the lens of SDGs; and ways to keep smallholders on 2030 agenda. International Journal of Sustainable Development \& World Ecology. https://doi.org/10.1080/13504509.2021.1905100

International Fund for Agricultural Development (IFAD). 2011. New realities, new challenges: new opportunities for tomorrow's generation. Rural Poverty Report 2011. IFAD, Rome, Italy.

International Fund for Agricultural Development (IFAD). 2016. Fostering inclusive rural transformation. Rural development report 2016. IFAD, Rome, Italy.

Kharas, H., J.W. McArthur and I. Ohno. 2019. Leave no one behind: time for specifics on the Sustainable Development Goals. Brookings Institution Press, Washington, DC, USA, 350 pp.

Krell, N.T., S.A. Giroux, Z. Guido, C. Hannah, S.E. Lopus, K.K. Caylor and T.P. Evans. 2020. Smallholder farmers' use of mobile service in Central Kenya. Climate and Development 13(3): 215-227. https:// doi.org/10.1080/17565529.2020.1748847 
Larson, D., K. Otsuka, T. Matsumoto and T. Kilic. 2014. Should African rural development strategies depend on smallholder farms? An exploration of the inverse-productivity hypothesis. Agricultural Economics 45(3): 335-367.

Lecouetre, E. 2017. The impact of agricultural co-operatives on women's empowerment: evidence from Uganda. Journal of Co-operative Organization and Management 5(1): 14-27.

Markelova, H., R. Meinzen-Dick, J. Hellin and S. Dohrn. 2009. Collective action for smallholder market access. Food Policy 34(1): 1-7.

Meinzen-Dick, R., A. Quisumbing, C. Doss and S. Theis. 2017. Women's land rights as a pathway to poverty reduction: framework and review of available evidence. Agricultural Systems 172: 72-82. https:// doi.org/10.1016/j.agsy.2017.10.009

Meinzen-Dick, R., N. Johnson, A.R. Quisumbing, J. Njuki, J.A., D. Behrman, D. Rubin, A. Peterman and E. Waithanji. 2014. The gender asset and its implications for agriculture and rural development. In: A.R. Quisumbing, R. Meinzen-Dick, T.L. Raney, A. Croppenstedt, J.A. Behrman and A. Peterman (eds.) Gender in agriculture: closing the knowledge gap. Springer, Cham, Switzerland.

Mikalitsa, S.M. 2010. Gender specific constraints affecting technology use and household food security in Western Province of Kenya. African Journal of Food Agriculture Nutrition and Development 10(4): 2324-2343.

Miller, B.A. 2001. Empowering women to achieve food security: rights to livestock. International Food Policy Research Institute, Washington. DC, USA.

Mojo, D., C. Fischer and T. Degefa. 2007. The determinants and economic impacts of membership in coffee farmer cooperatives. Recent evidence from rural Ethiopia. Journal of Rural Studies 50: 84-94.

Mwaura, F. 2014. Effect of farmer group membership on agricultural technology adoption and crop productivity in Uganda. African Crop Science Journal 22(s4): 917-927.

Naadira, N. 2012. Rural women's access to land in sub Saharan Africa and implications for meeting the millennium development goals. Agenda Empowering Women for Gender Equity 26(1): 41-53.

Netsayi, N.M., N. Mdege, P.E. Abidin and S. Bhatasara. 2017. The role of gender norms in access to agricultural training in Chikwawa and Phalombe, Malawi. Gender, Place \& Culture 24(12): 1689-1710.

Netsayi, N.M., T. Chevo, T. Nyekanyeka, E. Kapalasa and P. Demo. 2016. Gender norms and access to extension services and training among potato farmers in Dedza and Ntcheu in Malawi. The Journal of Agricultural Education and Extension 22(3): 291-305.

Nieminen, P., L. Lehtiniemi and K. Vahakangas. 2013. Standardised regression coefficient as an effect size index in summarising findings in epidemiological studies. Epidemiology Biostatistics and Public Health 10: 4.

Nkuranga, T. and K. Wilcox. 2013. Cooperative performance index. Field results and analysis. enabling market integration through rural group empowerment. (EMERGE) USAID, Washington, DC, USA.

Olagunju, K.O., A.I. Ogunniyi, Z. Oyetunde-Usman, A.O. Omotayo and B.A. Awotide. 2021. Does agricultural cooperative membership impact technical efficiency of maize production in Nigeria: an analysis correcting for biases from observed attributes. PLOS ONE 16(1): e0245426.

Palacios-Lopez, A., L. Christianen and T. Kilic. 2017. How much of the labor in African agriculture is provided by women? Food Policy 67: 52-63.

Poole, N. and A. Frece. 2010. A review of existing organisational forms of smallholder farmers' associations and their contractual relationships with other market participants in the East and Southern African ACP region. All ACP Agricultural Commodities Programme, FAO, Rome, Italy.

Poultron C., A. Dorward and J. Kydd. 2010. The future of small farms: new directions for services, institutions, and intermediation. World Development 38(10): 1413-1428.

Quisumbing, A.R. and J.A. Maluccio. 2000. Intrahousehold allocation and gender relations: new empirical evidence from four developing countries. Food Consumption and Nutrition Division Discussion Paper No. 84. IFPRI, Washington, DC, USA.

Quisumbing, A.R. and L. Pandolfelli. 2010. Promising approaches to address the needs of poor female farmers: resources, constraints, and interventions. World Development 38(4): 581-592. https://doi. org/10.1016/j.worlddev.2009.10.006 
Quisumbing, A.R., D. Rubin, C. Manfre, E. Waithanji, M. Van den Bold, D. Olney, N. Johnson and R. Meinzen-Dick. 2015. Gender assets, and market-oriented agriculture: learning from high-value crop and livestock projects in Africa and Asia. Agriculture and Human Values 32: 705-725.

Riesgo, L., K. Louhichi, S. Gomez, P. Hazell, R.J. Gilbert, S. Wiggins, D.F. Sahn and K.A. Mishra, 2016. Food and nutrition security and role of smallholder farms: challenges and opportunities. JRC Conference and Workshop Reports. European Commission, Brussels, Belgium.

Saito, K., H. Mekonnen and D. Spurling. 1994. Raising the productivity of women farmers in sub-Saharan Africa. World Bank Discussion Paper No. 230. World Bank, Washington, DC, USA.

Schneider, F., A. Buehn and C.E. Montenegro. 2010. Shadow economies all over the world. Policy Research Working Paper 5356. World Bank, Washington, DC. USA.

Sexsmith, K. 2019. Leveraging voluntary sustainability standards for gender equality and women's empowerment in agriculture: a guide for development organizations based on the sustainable development goals. International Institute for Sustainable Development, Winnipeg, Canada.

Shiferaw, B.A. and G. Murich. 2011. Farmer organizations and collective action institutions for improving market access and technology adoption in sub-Saharan Africa: review of experiences and implications for policy. In: ILRI (ed.) Towards priority actions for market development for African farmers. International Livestock Research Institute, Nairobi, Kenya, pp. 293-313.

Smith, L., U. Ramakrishnan, A. Ndiaye, L. Haddad and R. Martorell. 2003. The importance of women's status for child nutrition in developing countries. International Food Policy Research Institute, Washington, DC, USA.

Spielman, D.J., D. Kelemwork and D. Alemu. 2011. Seed, fertilizer, and agricultural extension in Ethiopia. International Food Policy Research Institute (IFPRI9: Ethiopia Strategic Support Program (ESSP)), Working Paper 020. IFPRI, Washington, DC, USA.

Sumelius, J., S.Tewaw, K.F. Bee and S. Chambo. 2015. Agenda on cooperatives for development cooperation in Tanzania. Journal of Co-operative Organization and Management 3: 98-100.

The County Government of Kakamega. 2013. The first county integrated development plan 2013-2017. County Government of Kakamega, Kakamega, Kenya.

UNICEF. 2013. Improving child nutrition - the achievable imperative for global progress. UNICEF, New York, NY, USA.

Wanyama, F.O. 2014. Cooperatives and the sustainable development goals: a contribution to the post-2015 development debate. A policy brief. International Labour Organization, Geneva, Switzerland.

Wanyama, F.O., P. Develtere and I. Pollet. 2009. Reinventing the wheel? African cooperatives in a liberalized economic environment. Annals of Public and Cooperative Economics 80(3): 361-392. https://doi. org/10.1111/j.1467-8292.2009.00390.x

Wennink, B., S. Nederlof and W. Heemskerk (eds.) 2007. Access of the poor to agricultural services. The role of farmers' organizations in social inclusion. KIT Publishers, Amsterdam, the Netherlands.

Wooldridge, J. 2013. Introductory econometrics: a modern approach, $5^{\text {th }}$ edition. South-Western College Publishing, Nashville, TN, USA.

Woomer, P.L., M. Omare and E.J. Mukhwana. 2004. The operations of rural self-help groups. In: C.N. Savala, M.N. Omare and P.L.Woomer (eds.) Organic resources management in Kenya: perspectives and guidelines. FORMAT, Nairobi, Kenya, pp. 131-146.

World Bank. 2007. Global economic prospects. Managing the next wave of globalization. Global Economic Prospects and the Developing Countries. World Bank, Washington, DC, USA.

World Bank. 2008. Agriculture for development. World Development Report 2008. World Bank, Washington, $\mathrm{DC}, \mathrm{USA}$.

World Bank. 2018. Poverty and equity data portal. World Bank, Washington, DC, USA.

World Bank. 2019. Gender statistics. World Bank, Washington, DC, USA. Available at: https://datacatalog. worldbank.org/dataset/gender-statistics

Wossen, T., T. Abdoulaye, A. Alene, M.G. Haile, S. Feleke, A. Olanrewaju and V. Manyong. 2017. Impacts of extension access and cooperative membership on technology adoption and household welfare. Journal of Rural Studies 54: 223-233. 